\title{
AgAINST THE ODDS: PROTECTION OF ECONOMIC, SOCIAL, AND CULTURAL RIGHTS BY THE CONSTITUTIONAL COURT OF UKRAINE
}

\author{
Yurii Sheliazhenko* \\ KROK University, Kyiv, Ukraine \\ sheliazhenkoiuv@krok.edu.ua
}

Received: 7 January 2020 | Revised: 11 April 2020 | Accepted: 15 April 2020

\begin{abstract}
The article traces historical development, doctrine, and impact of constitutional review in Ukraine related to matters of social justice. It is shown that international review of Ukraine's reports on observance of human rights obligations indicated a low level of compliance during the absence of independent constitutional review by the judiciary. After the establishment of the constitutional review, the compliance was improved against all doubts, whether socio-economic rights are justiciable in the Ukrainian context, and whether the judges are empowered enough to reshape authoritarian policies. Constitutional Court of Ukraine developed a doctrine of social justice based on the values of the rule of law, liberty, and equality, founding a pragmatic balance between the imperatives of individual freedom and economic security. In legal reasoning, judges implemented ideas of the human-centered state and personal autonomy in civil society, close to liberal democratic views, expressed by framers of the Constitution of Ukraine.
\end{abstract}

Keywords: Constitutional Court of Ukraine, Democratic Nation-building, Economic Security, Human Rights, Personal Autonomy, Social Justice.

Research Associate of the Faculty of Law at KROK University. 


\section{INTRODUCTION}

During the 1948 United Nation (UN) General Assembly in Paris, Ukraine abstained from the vote for the Universal Declaration of Human Rights (adopted by 48 votes of 58 ), criticizing it for lack of emphasis on economic and social rights. ${ }^{1}$ This ideologically driven move revealed a superficial attitude of the communist regime to the issue. Later, when Ukraine aligned with the majority of nations taking on human rights obligations, it was always a puzzle, how serious is the commitment. The legal system of post-communist Ukraine tried hard to make it serious.

This research is aimed to describe, analyze, and discuss historical development, doctrine, and impact of constitutional review in Ukraine related to matters of social justice, focusing on the performance of the Constitutional Court of Ukraine in its mission to uphold and enforce economic, social, and cultural rights.

Relevant literature in the field includes mainly doctrinal, but also political and economic studies, discussing the nature, scope, and justiciability of the socio-economic and cultural rights, as well as domestic and global instruments of its protection.

The fundamental value of human dignity, protected by the Constitution of Ukraine, includes access to minimal social benefits needed to ensure a sufficient and decent standard of living, stated Constitutional Court of Ukraine in 2018 decision. ${ }^{2}$ Natalia Shaptala, former Chairman of the Court, also said the Constitution of Ukraine prescribes an extremely wide spectrum of social rights, but it is important to make them real in practice, not still in declarations as usual. ${ }^{3}$

Constitution of Ukraine was adopted in 1996, three years after 1993 World Conference on Human Rights in Vienna, and incorporated a wide scope of standards contained in international human rights instruments, as urged Vienna

Eleanor Roosevelt, "Human Rights," in Peace on Earth (New York: Hermitage House, 1949), 66-7.

No 9-r/2018 of 7 November 2018 (Decision of the Constitutional Court of Ukraine, 2018).

"Konstytutsiina yustytsiia ta rynkova ekonomika: suchasni ta perspektyvni naukovo-praktychni realii" [Constitutional Justice and Market Economy: Contemporary Scientific and Practical Trends and Prospects]," Constitutional Court of Ukraine, accessed on 15 November 2019, http://www.ccu.gov.va/novyna/konstytuciyna-yustyciya-ta-rynkovaekonomika-suchasni-ta-perspektyvni-naukovo-praktychni. 
Declaration and Programme of Action. ${ }^{4}$ Articles 1, 3 of the Constitution say that Ukraine is a sovereign and independent, democratic, social, law-based state; the human being, his or her life and health, honor and dignity, inviolability and security are recognized in Ukraine as the highest social values. ${ }^{5}$ Chapter II of the Constitution, named "Human and Citizen's Rights, Freedoms and Duties," have many marks of the precise wording of core international human rights treaties, including International Covenant on Economic, Social and Cultural Rights (ICESCR).

There are a number of doctrinal and comparative publications suggesting that constitutional review can play an important role in the protection of the rights enshrined in ICESCR, especially in the context of transitional justice. United Nation - the Office of the High Commissioner for Human Rights (UN OHCHR) notes that a number of national constitutional courts and regional treaty bodies like European Court of Human Rights (ECtHR) provide remedies against violations of the rights; ${ }^{6}$ for example, the Colombian Constitutional Court ordered the Government should ensure right to a minimum standard of living for internally displaced persons. ${ }^{7}$ Chinkin described ways of post-conflict restoration of socio-economic rights. ${ }^{8}$

Christian Courtis, in a comprehensive report on social justice adjudication at international, regional, and domestic levels, written for International Commission of Jurists, discussed various objections to the justiciability of economic, social, and cultural rights, such as uncertain content of the rights, procedural difficulties, and lack of judicial capacity. To refute the objections, he analyzes cases and practices from different jurisdictions and links socio-economic rights with civil and political rights, universally recognized as justiciable. For example, he points out

\footnotetext{
United Nations, "Vienna Declaration and Programme of Action" (World Conference on Human Rights, A/ CONF.157/23, 12 July 1993).

5 Constitution of Ukraine.

6 UN Office of the High Commissioner for Human Rights, Economic, Social and Cultural Rights: Handbook for National Human Rights Institutions (New York and Geneva: United Nations, 2005).

7 UN Office of the High Commissioner for Human Rights, Transitional Justice and Economic, Social and Cultural Rights (Geneva: United Nations, 2014).

8 Christine Chinkin, "The Protection of Economic, Social and Cultural Rights Post-Conflict" (Paper series commissioned by the Office of the High Commissioner for Human Rights, 2009), http://www2.ohchr.org/english/issues/women/ docs/Paper_Protection_ESCR.pdf.
} 
on inconsistency of argument that, under the principle of separation of powers, the judiciary should not encroach on the domain of other branches of power, namely the legislative and the executive powers responsible for welfare policies. Judicial review of political decisions is a part of the mutual control of powers, often described as "checks and balances," which guarantees the inviolability of civil and political rights. Courtis argues that it must also work for socio-economic rights since all human rights are interconnected. 9

Several authors highlighted the impact of austerity policies on the constitutional protection of economic, social and cultural rights. Swaminathan suggested that national enforcement of socio-economic rights, undermined by structural adjustment programs of the International Monetary Fund and the World Bank, may help the people of developing countries to retake control over their governments, compromised by the international financial system. ${ }^{10}$ Michalowski studied how conflicts between social rights and sovereign debt obligations can be resolved under international law, particularly with regard to the constitutional justiciability of social rights." The issue was raised with references to case law of constitutional courts in a monograph of Ssenyonjo, discussing possible establishment of a World Court of Human Rights, ${ }^{12}$ and in edited books, such as "Sovereign Debt and Human Rights" highlighting role of the judiciary in definition of minimal core human rights obligations, ${ }^{13}$ and "Making Sovereign Financing and Human Rights Work" where constitutional review of economic emergencies invocation is discussed. ${ }^{14}$

Landau studied models of social rights enforcement by the courts in several countries, criticizing the "negative means" such as striking down a law and individualized rights enforcement. He argues the judiciary should issue positive

9 Christian Courtis, Courts and the Legal Enforcement of Economic, Social and Cultural Rights: Comparative Experiences of Justiciability (Geneva: International Commission of Jurists, 2008).

10 Rajesh Swaminathan, "Regulating Development: Structural Adjustment and the Case for National Enforcement of Economic and Social Rights," Columbia Journal of Transnational Law 37, no. 1 (1998): 161.

11 Sabine Michalowski, "Sovereign Debt and Social Rights - Legal Reflections on a Difficult Relationship," Human Rights Law Review 8, no. 1 (2008): 35-68, https://doi.org/10.1093/hrlr/ngmo42.

12 Manisuli Ssenyonjo, Economic, Social and Cultural Rights in International Law (Oxford: Hart Publishing, 2009).

${ }_{13}$ Ilias Bantekas and Cephas Lumina, eds., Sovereign Debt and Human Rights (Oxford University Press, 2019).

${ }_{14}$ Juan Pablo, Bohoslavsky, and Jernej Letnar Cernic, eds., Making Sovereign Financing and Human Rights Work (Oxford: Hart Publishing, 2016). 
orders forcing the state to provide social services because structural changes and innovative remedies are needed to protect the poor and deal with social injustices. ${ }^{15}$

According to doctrinal studies, the Constitutional Court of Ukraine developed a systemic approach to matters of social justice. Holovaty notes that the Court many times expressed in judgments strict view that in social and law-based state idea of social justice must be guaranteed by the rule of law and embodied into law-making and law-enforcement activities of the State. ${ }^{16}$

Verlanov scrutinized the Court's application of the Universal Declaration of Human Rights, ICESCR and European Social Charter (revised), studied methods of rights protection by the Court. ${ }^{17}$ Inshyn, Miroshnychenko, and Paida highlighted the importance of the Court's judgments for the protection and development of constitutional cultural rights and freedoms. ${ }^{18}$

Bulkat critically analyzes opinions of the Court, pointing to contradictions between upheld rights and recognition of the limited economic capacity of the state to deliver social benefits. ${ }^{19}$ Judge Chubar highlighted socio-economic rights protection of vulnerable categories of people by the Court, including victims of Chernobyl disaster, military and law enforcement personnel, pensioners and veterans; also he admitted that Ukraine for a long time arranged increase in spending on social benefits, which become the burden for the state budget undermining stability of financial system, especially in view of low effectiveness of welfare programs in Ukraine (20-22\%) comparing to the similar programs in Eastern and Western Europe with 30-50\% effectiveness rates. ${ }^{20}$

\footnotetext{
15 David Landau, "The Reality of Social Rights Enforcement," Harvard International Law Journal 53, no. 1 (Winter 2012): 189-247.

16 Serhiy Holovaty, "Concept of the Rule of Law - Difficulties of its perception in the post-Soviet legal culture (Ukraine's experience)," (Report, Venice Commission, 2016), accessed on 15 November 2019, https://www.venice. coe.int/webforms/documents/?pdf=CDL-JU(2016)015-e.

${ }_{17}$ Serhii Verlanov, Ekonomichni i sotsialni prava liudyny: yevropeiski standarty ta yikh vprovadzhennia $v$ yurydychnu praktyku Ukrainy (zahalnoteoretychne doslidzhennia) [Economic and social rights of human: European standards and their implementation in judicial practice in Ukraine (broad theoretical research)] (Lviv: Krai, 2009).

18 Mykola Inshyn, Yurii Miroshnychenko, and Yurii Paida, "Protection of Constitutional Cultural Rights and Freedoms of Citizens by The Constitutional Court Of Ukraine," Baltic Journal of Economic Studies 4, no. 4 (2018): 134-9. https://doi.org/10.30525/2256-0742/2018-4-4-134-139.

19 Liudmyla Bulkat, "Pytannia sotsialnoho zakhystu v aktakh Konstytutsiinoho Sudu Ukrainy [The issue of social protection in the acts of the Constitutional Court of Ukraine]," University Scientific Notes 58 (2016): 23-34.

20 Liudmyla Chubar, "Problemy realizatsii sotsialnykh prav na suchasnomu etapi ta yikh zakhyst u konstytutsiinomu
} 
Among notable achievements of the Court, former Chairman Judge Holovin mentioned decisions in the cases concerning labor and welfare rights. ${ }^{21}$ Former Chairman Judge Baulin pointed out the influence of judgments of the European Court of Human Rights (ECtHR) on legal reasoning of the Constitutional Court of Ukraine, in particular in cases concerning social benefits. ${ }^{22}$ The procedure of the constitutional complaint in Ukraine was also studied by Faiz. ${ }^{23}$

The Constitutional Court of Ukraine is the sole body of constitutional jurisdiction in Ukraine and composed of 18 judges, appointed by the President, by the Verkhovna Rada (parliament), and by the congress of judges, each of which appoints 6 judges for 9-years term, who cannot be reappointed. The mixed composition of the Court predetermines its relative independence and plurality of legal thoughts represented there, also abundantly expressed in dissenting opinions published with mega political judgments. There is possibly a field for further study of judicial politics, strategic behavior of judges, etc. But this research is focused rather on the dynamics and outcome of constitutional review, according to the methodical requirement to take into account the autonomy of legal processes as explained in another article of the author. ${ }^{24}$

Among 295 summaries of opinions and decisions of the Constitutional Court of Ukraine published in English in the constitutional database of Venice Commission, ${ }^{25}$ representing near $74 \%$ of total opinions and decisions, ${ }^{26}$ there are

sudochynstvi [Contemporary problems of realization of social rights and its defense in constitutional justice]," The Herald of the Constitutional Court of Ukraine 6 (2003):111-4.

21 Anatolii Holovin, "15 Years of Constitutional Justice in Ukraine: Accomplishments, Challenges, Prospects," in The Protection of Human Rights by Bodies Of Constitutional Justice: Possibilities And Problems of Individual Access. Materials of International Conference (Kyiv: Logos, 2011), 411-24.

22 Yurii Baulin, "The Jurisprudence of the Constitutional Court of Ukraine on the Protection of Human Rights Recognized by the Ukrainian Legislation and Acts of International Law," in Global Constitutionalism and Multilayered Protection of Human Rights - Exploring the Possibility of Establishing a Regional Human Rights Mechanism in Asia (Seoul: Constitutional Court of Korea, 2016), 133-67.

23 Pan Mohamad Faiz, "A Prospect and Challenges for Adopting Constitutional Complaint and Constitutional Question in the Indonesian Constitutional Court," Constitutional Review 2, no. 1 (2016): 103-28, http://dx.doi. org/10.31078/consrev215.

24 Yurii Sheliazhenko, "Autonomous Processual Model of Law," Philosophy of Law and General Theory of Law 1 (2019): 91-111. https://doi.org/10.21564/2227-7153.2019.1.186739.

25 "The CODICES database," European Commission for Democracy through Law (Venice Commission), Council of Europe, accessed on 15 November 2019, http://www.codices.coe.int.

26 Since 1996, the Court issued 361 decisions and 37 opinions searchable and accessible in Ukrainian at the official website of Constitutional Court of Ukraine (http://ccu.gov.ua/en) and in the Legislation of Ukraine Database (https://zakon.rada.gov.ua/laws?lang=en). 
54 linked by thesaurus to the category "Economic, social and cultural rights." The author selected 26 cases of the sort (see Appendix) on the base of doctrinal and political significance for further historically embedded analysis.

The results of this research are laid in Section II, which consists of five subsections. Historical background before the establishment of the Court in Subsection 2.1 helps to understand the origins and necessity of constitutional review. Subsection 2.2 describes the framework of the review and discusses doubts concerning power and independence of the Court. Doctrinal principles of social justice explained in Subsection 2.3, and the Court's intercourse with economic and political turbulence is discussed in Subsection 2.4 to conceptualize a balanced judicial approach to the protection of social, economic and cultural rights. Subsection 2.5 assesses the impact of the Court's jurisprudence to address the doubts about the non-binding, declarative character of socio-economic rights. Findings of the article help to understand how constitutional justice can make the political and economic transition more fair and legal, since the Ukrainian experience can be helpful to other nations in transition, and to formulate proposals aimed to strengthen constitutional review in the matters of social justice.

\section{ANALYSIS AND DISCUSSION}

\subsection{Protection of Economic, Social and Cultural Rights before the Establishment of the Constitutional Court of Ukraine}

Ukraine signed International Covenant on Economic, Social and Cultural Rights (ICESCR) in 1968 and ratified it in 1973. In the first periodic report ${ }^{27}$ on implementation of the covenant, submitted in 1978, government of Ukrainian Soviet Socialist Republic (SSR) claimed that "The rights and freedoms recognized in the Covenant were guaranteed to the citizens of the Ukrainian SSR long before that international instrument entered into force." Indeed, economic, social and cultural rights (including rights to work, fair remuneration, leisure, education,

\footnotetext{
27 United Nations, Economic and Social Council, "Reports submitted in accordance with Council resolution 1988 $(L X)$ by states parties to the International Covenant on Economic, Social and Cultural Rights covered by articles 6 to 9: Ukranian Soviet Socialist Republic" (E/1978/8/Add.22, 26 September 1978).
} 
social security, and medical care) were prioritized in 1937 Constitution of Ukrainian SSR before the civil and political rights (severely restricted to ensure the rule of communist party ${ }^{28}$ with further proclamation in Article 37 of 1978 Constitution of Ukrainian SSR ${ }^{29}$ that "the socialist system ensures enlargement of the rights and freedoms of citizens and continuous improvement of their living standards through the fulfillment of social, economic and cultural development programs."

According to the mentioned periodic report, state funding of social benefits for workers increased from 1.670 million roubles in 1970 to amount of 2.630 million roubles in 1976; also, during consideration of the report in 1980 the state informed about its efforts to finance and organize the construction of housing available to citizens at low rents, $3-5 \%$ of family income, so in 1976-1980 over 6 million people had received the housing. ${ }^{30}$

However, the report also claimed "the complete absence of unemployment, which was eliminated in the country as early as 1930." The same statement in second periodical report ${ }^{31}$ of Ukrainian SSR caused many questions during an expert discussion in 1984 working group session, ${ }^{32}$ on which Fedir Burchak, representative of Ukrainian SSR, gave dodgy answers. He explained by "advantages of planned economy" extraordinary growth of declared number of jobs after 1970. Also, he concealed criminalization of unemployment and homelessness, claiming that constitutional provisions forbidding evasion from socially useful work "carried no sanctions."

In fact, older constitutions of Ukrainian SSR of 1919 and 1929 were recognized no right to work but obligation to work; these constitutions were manifestly deprived of any rights those who don't belong to working class. According to

8 Constitution (The Basic Law) of the Ukrainian Soviet Socialist Republic of 1937.

29 Constitution (The Basic Law) of the Ukrainian Soviet Socialist Republic of 1978.

30 United Nations, Economic and Social Council, "Sessional working group on the implementation of the International Covenant on Economic, Social and Cultural Rights: summary record of the 18th meeting" (E/1980/WG.I/SR.18, 28 April 1980).

${ }^{31}$ United Nations, Economic and Social Council," Implementation of the International Covenant on Economic, Social and Cultural Rights. Second periodic reports submitted by States parties to the Covenant concerning rights covered by articles 6 to 9 in accordance with the first stage of the programme established by the Economic and Social Council in its resolution 1988 (LX): Ukranian Soviet Socialist Republic," E/1984/7/Add.9 (13 March 1984).

32 United Nations, Economic and Social Council, Sessional working group of governmental experts on the implementation of the International Covenant on Economic, Social and Cultural rights: summary record of the 15th meeting, E/1984/WG.1/SR.15 (30 April 1984). 
Article 214 of the 1960 Criminal Code of Ukrainian SSR, vagrancy, begging, and parasitic lifestyle were punishable by imprisonment or correctional labor for a term of one to three years. This article, repressing the unemployed, was in force until 1992, despite soviet leader Khrushchev in 1961 declared an end to the "dictatorship of the working class," introduced by Lenin in the first years of 1917 revolution and developed by Stalin during next decades, including creation of the Gulag system of forced labor camps. Attempt of Communist party in the second half of XX century to create welfare state ensuring a livelihood to all workers, according to Marxist principles, without robust economic culture led to shortages of consumer goods and services and subsequent collapse of socialist economy. Concealed patterns of unemployment in Soviet Union were revealed by western surveys long time before its dissolution, as well as low labor productivity of oppressed and underpaid population ${ }^{33}$ (popular saying of the time - "In the Soviet Union the people are pretend to work, and communists are pretend to pay").

Ukraine started to publish statistics of unemployment only after gaining independence, and yet, as admitted in third periodical report ${ }^{34}$ of 1994, official figure 181 ooo of unemployed citizens does not reflect real situation of the time, namely the hidden unemployment of $\mathbf{2 . 2}$ million of people, or $9 \%$ of working age population. So, governmental data remained questionable even in postsoviet Ukraine.

Another indicator of injustice, observed both in soviet and independent Ukraine, is deep social inequality. Despite in Ukrainian SSR and other republics of USSR advanced system of social welfare was built with universal services widely available, there was generally low level of service and unfair redistribution of resources in favor of the nomenclature of the Communist party and elite in capital cities; while some people enjoyed the benefits of socialist welfare,

33 Paul R. Gregory and Irwin L. Collier Jr., "Unemployment in the Soviet Union: Evidence from the Soviet Interview Project," The American Economic Review 78, no. 4 (1988): 613-32. See also: José Luis Ricón, "The Soviet Union: Achieving full employment," Nintil, https://nintil.com/the-soviet-union-achieving-full-employment/.

34 United Nations, Economic and Social Council, Ukraine: implementation of the International Covenant on Economic, Social and Cultural Rights. Third periodic reports submitted by States parties under articles 16 and 17 of the Covenant, E/1994/104/Add.4 (17 October 1994). 
others were excluded. ${ }^{35}$ This inequality became drastic after free-market reforms. In 2001, during the consideration of the fourth periodic report of Ukraine in UN Committee on Economic, Social and Cultural Rights, judge Ariranga Pillay mentioned, referring to the UNDP report, that $30 \%$ of the population of Ukraine was poor and $15 \%$ lived in abject poverty. He pointed out that such poverty was in part attributable to the process of economic transition, which had served to enrich only a tiny minority; poverty affected the most vulnerable segments of the population, especially the elderly, women and children, in a variety of ways, including prostitution, child abandonment and trafficking. ${ }^{36}$ Described crisis of social justice, in our view, vividly highlighted need of constitutional review during the political and economic transition to prevent unfavorable outcomes, such as abyss of inequality, mass poverty, and rampant crime.

Ukraine had come a long way to introducing the institute of constitutional review by the independent judiciary body. In the time of ratification of ICESCR, Ukrainian SSR was part of the Soviet Union where no jurisdiction of judges to change the law was recognized. The constitutional supervision was conducted nominally by the legislatures of the union and member republics, expected to control somehow their own extensive powers. In Soviet Ukraine ensuring observance of the Constitution was a function of the Presidium (standing body) of the Verkhovna Rada (legislature) of the Ukrainian SSR, which also was the highest body of state authority in Ukrainian SSR; courts enforced rights of citizens accordingly to the laws having no authority to question its constitutionality; the Procurator-General of USSR with subordinated to him Procurator-General of Ukrainian SSR and local procurators were responsible for overall (with exception to legislatures) supervision of the strict and uniform observance of laws. ${ }^{37}$

In 1989 Committee of Constitutional Supervision of the USSR was established ${ }^{8}$ and influenced the field of law in Ukrainian SSR during subsequent years before

35 Elena larskaia-Smirnova and Karen Lyons, "Social Work in Former Soviet Union Countries: Mapping the Progress of 'The Professional Project'," European Journal of Social Work 21, no. 1 (2018): 114-27. https://doi.org/10.1080/ 13691457.2016 .1255926$.

36 United Nations, Economic and Social Council, Committee on Economic, Social and Cultural Rights Twenty-sixth (extraordinary) session: summary record of the 41st meeting, E/C.12/2001/SR.41 (28 August 2001).

37 Leonid Yuzkov, Constitution of Soviet Ukraine (Kyiv: Politvidav Ukraini Publishers, 1984).

${ }^{38}$ Herbert Hausmaninger, "The Committee of Constitutional Supervision of the USSR," Cornell International Law Journal 23, no. 2 (1990): 287-322. 
the dissolution of the Soviet Union in 1991. Dr. Fedir Burchak, mentioned before, became a member of the Committee in the capacity of the Head of Legal Division of the Presidium of the Verkhovna Rada of Ukrainian SSR. In particular, the Committee declared unconstitutional and void some restrictions of rights to work, education, and protection of the family of Soviet citizens on the basis of propiska, which was residency permit and instrument of state control over internal migration, especially into main cities (Moscow and Leningrad in Russia, Kyiv in Ukraine were strictly mentioned in the resolution of the Committee ${ }^{39}$ ).

In 1989 Verkhovna Rada amended the Constitution to establish the Committee of Constitutional Supervision of Ukrainian SSR, but this decision was never implemented. Instead, in 1990 Verkhovna Rada amended the Constitution again introducing the Constitutional Court, but failed to elect judges of the court next years due to conflict between parliament and president. Only the head of the Constitutional Court, Leonid Yuzkov was elected and appointed to chair the Working Group of the Constitutional Commission of Ukraine, designed to draft the new Constitution of Ukraine. In 1992, Ukraine applied to join the Council of Europe, so its Commission for Democracy through Law, known as the Venice Commission, was involved in the drafting.

In 1993 at the invitation of Mr. Yuzkov four Venice Commission's rapporteurs accompanied by the secretary were traveled to Kyiv, received by President Leonid Kravchuk and met with the members of Constitutional Commission. During the meeting and in the next opinions on Ukrainian constitutional reform (in particular, evaluating in 1997 its outcome ${ }^{40}$ ) Venice Commission raised concerns about abundance of socio-economic rights in the new constitution, noting that "The list of human rights appears to be exhaustive and in line with international instruments, but some of these rights seem to be more political goals than real, enforceable rights," so it may cause unrealistic expectations among the people and inability of courts to protect these rights, undermining the rule of law. Answering the concerns, "The Ukrainian hosts explained that this is due to the

\footnotetext{
39 Committee of Constitutional Supervision of the USSR, "Conclusion concerning legislation on propiska of citizens" (No 11(2-1), 26 October 1990).

40 "Opinion on the Constitution of Ukraine, CDL-INF(1997)002-e," Council of Europe, Venice Commission, 11 March 1997.
} 
constitutional tradition prevailing in the country, and to the fear that the people might not appreciate a constitution without such provisions," as quoted in the memorandum after the meeting. ${ }^{41}$ Wolczuk puts out that full protection of social and economic rights for the moment was the agenda of left-wing parties when their right-wing opponents were concerned only with enforcement of Ukrainian ethnic identity after the centuries of russification under the Moscow imperial rule. As for pro-presidential centrists, they were seeing in socio-economic rights no more than an impediment to free-market reforms. ${ }^{42}$ When the constitutional agreement was reached in 1995, no efforts were made by the legislators to develop a more pragmatic approach to constitutional rights, especially socio-economic ones; as suggested Venice Commission, maintenance in force de-jure these rights which were ineffective de-facto for the sake of popular demand and national cohesion can offer ground for interventions by the Constitutional Court. ${ }^{43}$

After the adoption of the new Constitution of Ukraine in 1996, a new law on the Constitutional Court was passed; judges were appointed and took an oath on 18 October 1996, so the court started to function. One of the first decisions in 1997 was stated that Verkhovna Rada henceforth has no authority to give an official interpretation of the Constitution it solely performed by previous decades since this authority under the new Constitution belongs to the Constitutional Court of Ukraine. ${ }^{4}$

For that time, the country was suffered from an economic crisis caused by a transition from socialist to a market economy: labor income fell in a half, large arrears were accumulated in wage and pension payments, majority of the population lived in poverty receiving different forms of social benefits. 45

\footnotetext{
${ }_{41}$ "Meeting on the draft Constitution of Ukraine: Secretariat memorandum, CDL(1993)042-e," Council of Europe, Venice Commission, 25 June 1993.

42 Kataryna Wolczuk, The Moulding of Ukraine: The Constitutional Politics of State Formation (Budapest: Central European University Press, 2001).

43 "Opinion on the present constitutional situation in Ukraine following the adoption of the Constitutional Agreement between the Supreme Rada of Ukraine and the president of Ukraine, CDL(1995)040-e," Council of Europe, Venice Commission, 11 September 1995.

44 Ivan Tymchenko, "Mechanism of Constitutional Jurisdiction in Defence of Rights and Freedoms of Man and Citizen," in Yurii Bytiak et al., eds., The Legal System of Ukraine: Past, Present, and Future. Volume II. Constitutional Foundations of the Legal System of Ukraine and Problems of Improvement (Kharkiv: Pravo, 2013): 121-47.

45 John Odling-Smee et al., Ukraine: IMF Economic Reviews (Washington: International Monetary Fund, 1995).
} 
In the next years, the suffering became deeper after the world economic crisis of 2008 and armed conflict in Eastern Ukraine started in 2014. In that context Constitutional Court of Ukraine developed a doctrine of the rule of law based on social justice and issued a number of judgments protecting vulnerable categories of people from socio-economic and cultural deprivation, enforcing human rights guaranteed by the Constitution of Ukraine. The Court interpreted these rights in light of international treaties ratified by Ukraine - in particular, ICESCR, European Convention on Human Rights, and European Social Charter (Revised), the last ratified in 2006 with significant reservations, excluding the right to social and medical assistance, protection of migrant workers and their families, and the right of workers to the protection of their claims in the event of the insolvency of their employer.

\subsection{Constitutional Framework and the Powers of the Court}

Human rights in economic, social and cultural spheres are comprehensively implemented in Section II of the Constitution of Ukraine, including some formulations enshrining personal autonomy. In particular, Article 43 guarantees everyone right to work he or she free chose, as well as the right to proper, safe, and healthy labour conditions, and to remuneration no less than the minimum wage determined by law. Article 45 enshrines the worker's right to rest. Article 36 guarantees the right of citizens to form trade unions and join the trade union, and Article 44 guarantees the right of workers to strike. Right of citizens to social security is guaranteed by Article 46, and right of everyone to a sufficient standard of living according to Article 48 includes adequate nutrition, clothing, and housing; Article 47 particularly protects right to housing. Article 49 guarantees everyone the right to health protection, medical care, and medical insurance. Accordingly to Article 53, everyone shall have the right to education, and complete general secondary education shall be compulsory. The freedom of literary, artistic, scientific, and technical creative activities, as well as protection of intellectual property guaranteed to citizens by Article 54 . Article 51 prescribes the state protection of family, childhood, motherhood, and fatherhood. Equality of all human beings in dignity and rights is recognized in Article 21; Article 23 
guarantees the right of everyone to free development of personality, and Article 24 proclaims equal constitutional rights of citizens, as well as equality of the rights of women and men.

Even though the Constitution of Ukraine does not guarantee progressive socio-economic development supported by maximum available resources, it contains formal safeguards to prevent a decline in achieved standards of social justice. Article 22 prohibits the abolition of constitutional rights. Also, Article 64 prohibits restriction of constitutional rights, unless such restriction stipulated by the Constitution; according to the article, such restrictions can't be imposed on the rights to non-discriminatory treatment, to housing, to protection of family, parenthood, and childhood, but other socio-economic rights can be restricted on temporary basis under martial law or a state of emergency.

Also, as mentioned above, some human rights in the Constitution of Ukraine are literally guaranteed to citizens, not to everyone. On the other hand, according to Article 26 of the Constitution, foreigners and stateless persons staying in Ukraine on legal grounds shall enjoy the same rights and freedoms and bear the same duties as citizens of Ukraine, except as restricted by the Constitution, laws, or international treaties of Ukraine.

Article 8 of the Constitution recognizes the principle of the rule of law. According to Article 9 of the Constitution, international treaties in force agreed to be binding by the Verkhovna Rada of Ukraine are an integral part of the national legislation. So, the rights guaranteed by ICESCR are the law and must be justiciable in Ukraine.

Jurisdiction of the Constitutional Court of Ukraine to decide on compliance with the Constitution of Ukraine (constitutionality) of laws and other legal acts, to provide the official interpretation of the Constitution of Ukraine, to provide opinions on the constitutionality of amendments to the Constitution, of international treaties, of questions that are proposed to be put for a referendum, and on the observance of the constitutional procedure of impeachment of the President of Ukraine is described in Section XII and Article 159 of the Constitution. Apart of individual constitutional complaints, the Constitutional Court of 
Ukraine considers constitutional petitions lodged by Authorised Human Rights Representative of the Verkhovna Rada of Ukraine (the ombudsman initiated many landmark cases of the Court), 45 or more People's Deputies of Ukraine, the President of Ukraine, and the Supreme Court.

Decisions and opinions adopted by the Constitutional Court of Ukraine are binding, final, and may not be challenged (Article 151.2). Laws and other legal acts or their particular provisions which the Court found unconstitutional lose their legal force, and damages caused by enforcement of unconstitutional acts must be compensated by the State (Article 152).

The Court's autonomy in controlling the judicial process is limited. Article 153 of the Constitution prescribes that the Constitution and law determine the organization, operation, and procedures of the Court. Decisions of the Court are not considered the law because the Constitution as basic and superior law requires in Articles 8 and 85 the laws shall be adopted by the Verkhovna Rada. This feature of the civil law system, in my view, means that judges formally are not trusted to make the law and must surrender to the political will of the legislators. Of course, in practice, judges inevitably made the law, at least in a broad theoretical sense (not the law in the strict constitutional terminology, i.e., statute law), vitalizing prescriptions of outdated, vague and contradictory statutes in complicated situations of real life, hardly foreseen by the legislators, as well as developing, upholding, and changing case law (which, by the way, many jurists denied to recognize as a source of law, even preferring to call it "court's practice," not the precedent). Many problems with the realization of economic, social, and cultural rights in Ukraine are caused by deprivation of personal autonomy, ${ }^{46}$ and the Constitutional Court of Ukraine, deprived of judicial autonomy, have a little opportunity to change the situation.

Despite Article 149 of the Constitution proclaims the independence of judges and prohibits any influence on a judge of the Constitutional Court of Ukraine, factual dependence of judges on political will is so deep that the Verkhovna Rada

46 Coalition for Personal Autonomy, "Ukraine: problems with implementation of the International Covenant on Economic, Social and Cultural Rights," Pravdoshukach, 31 August 2018, https://truth.in.ua/en/public/358/. 
and the President repeatedly influenced and incapacitated the Constitutional Court of Ukraine, blocking appointment or inauguration of judges, dismissing them and manipulating with adoption of procedural law. For example, after the 2016 changes to the Constitution of Ukraine, the Court was obliged to receive but unable to hear personal constitutional complaints until 2018 because of delay in the adoption of the new law about the Court, since the old law become discrepant to the Constitution. The function of the Constitutional Court of Ukraine was paralyzed by politicized dismissals of judges ${ }^{47}$ and holding their offices vacant ${ }^{48}$ during political crises in 2007 and in 2014; a number of judges were prosecuted for alleged involvement in seizure of power by the former president Yanukovych in 2010 who supposedly pushed the Court to overrule constitutional reform of 2004 and restore excessive presidential authority.49 Venice Commission warned in 1996 that the functioning of the Constitutional Court can be blocked by the non-appointment of judges, ${ }^{50}$ but this warning wasn't seriously considered, possibly because the political elite had no intention to strengthen independent constitutional review.

On the other hand, the composition of the Court, mixed from judges appointed by the legislative, executive, and judicial branches of power, ensures its relative independence and allows incorporating a pragmatic account of social justice into highly demanded adjudication of disputes between competing elites. This position of impartial adjudicator distinguishes the Constitutional Court of Ukraine from other courts in the country, often criticized for lack of impartiality and judicial independence..$^{51}$ A commitment of the Court to social justice helps it to remain impartial, gaining trust by upholding the core value of legal culture.

47 International Commission of Jurists, "Ukraine: dismissal and criminal prosecution of judges undermine independence of the judiciary," last modified on 20 March 2014, https://www.icj.org/ukraine-dismissal-and-criminal-prosecutionof-judges-undermine-independence-of-the-judiciary/.

48 Iryna Budz, "What Prevents Ukrainian Judiciary From Becoming Truly Effective And Independent?" VoxUkraine, last modified on 24 July 2019, https://voxukraine.org/en/what-prevents-ukrainian-judiciary-from-becoming-trulyeffective-and-independent/.

49 LB.ua, "Yanukovych charged with constitutional coup. Ex-Justice Minister Lavrynovych is another suspect in the case," last modified on 6 September 2017, https://en.lb.ua/news/2017/09/06/4436_yanukovych_charged.html.

50 Council of Europe, Venice Commission, "Opinion on the draft Constitution of Ukraine" (CDL-INF(1996)oo6-e, Council of Europe, Venice Commission, 21 May 1996).

51 Maria Popova, "Ukraine's Politicized Courts," in Beyond the Euromaidan: Comparative Perspectives on Advancing Reform in Ukraine, eds. Henry E. Hale and Robert W. Orttung (Stanford University Press, 2016), 143-61. 
Also, some elder judges themselves are interested in quiet retirement and social benefits; this factor not only constrain them from partisanship as observed Trochev $^{52}$ but encourage to establish a doctrinal link between social justice and judicial independence, as in 2016 decision ${ }^{53}$ concerning pensions of judges which claims that high social security of judges protects their impartiality and integrity.

\subsection{Social Justice by the Constitution: Rule of Law, Equal Treatment, and Autonomy}

Apart from pressure by corrupted politicians on the Court, another factor impeding justiciability of economic, social, and cultural rights proclaimed by the Constitution of Ukraine and international human rights treaties is a tendency to consider it simply as declarations of intentions imposing almost no legal obligations on the State. This view, in particular, can be found in official opinions and expert publications of the Venice Commission.

In 1996 opinion the Commission criticized the draft Constitution of Ukraine, pointing out, that "the very exhaustive character of the list including rights of a social, economic and environmental character poses problems for their guarantee by the courts." Also, the Commission found unsatisfactory the formulation of Article 3, paragraph 1 "the human being... is recognised in Ukraine as the highest social value." In view of Commission, it gives, at least in translation, the impression that the individual is seen in the function of society and not in its inherent value and dignity, which precedes the state, is unique, irreplaceable, and incomparable. 54

In 1997 opinion Venice Commission noted that the already adopted Constitution of Ukraine in Article 3 still considers the human being as the highest social value and not simply the highest value. Also, it expressed its skepticism concerning the justiciability of socio-economic rights "which have to be implemented on the basis of parliamentary statutes and executive action,"

\footnotetext{
52 Alexei Trochev, "Fragmentation? Defection? Legitimacy? Explaining Judicial Roles in Post-Communist Colored Revolutions," in Consequential Courts: Judicial Roles in Global Perspective, eds. Diana Kapiszewski, Gordon Silverstein, and Robert A. Kagan (Cambridge University Press, 2013), 82.

53 Case No 4-rp/2016 of 8 June 2016 (Decision of the Constitutional Court of Ukraine, 2016).

54 Supra, note 50.
} 
urging it is "unrealistic" to expect the implementation of these rights directly by the courts. ${ }^{55}$ Judge Mykhailo Hultai argued that socio-economic rights cannot be protected by the state and by the court, unless to the extent that they are a prerequisite for the implementation of civil and political rights and freedoms; therefore constitutional complaints appealing solely to these rights must be considered inadmissible..$^{56}$

It seems that constitutional emphasis on social character of the value of human was misunderstood by the experts of the Venice Commission. This emphasis doesn't diminish inherent value and dignity of individual, but demand to respect it in the social life. Interconnection and interdependence of all human rights, civil-political and social-economic-cultural, is well-known principle proclaimed in the Vienna Declaration and Programme of Action three years before the Constitution of Ukraine was adopted. Even critics of socio-economic rights such as judge Hultai can't deny that personal security and civil liberties of individual are weak if not supported by dignified standard of living, minimum means of existence in civilized society guaranteed by welfare state. Social security protects democracy and free-market from crime and radicalism induced by hopeless poverty. Taking apart disputable option of universal basic income, it is widely recognized that the welfare state is obliged to care for vulnerable groups assuming that the most of people are capable to take benefits of social life without the direct assistance of the state. Judge Chubar wrote: Article 48 of the Constitution of Ukraine proclaims the right of every citizen of Ukraine and his or her family to sufficient standard of living, including food, clothes, housing; but this in no way means that the state must provide everyone these livelihoods, instead the state creates an environment in which individuals can actively pursue the sufficient standard of living, and only if some citizens are certainly unable to do it, the state must provide to the needy social benefits in sum no less than a living wage. ${ }^{57}$

55 Supra, note 40.

${ }^{56}$ Mykhailo Hultai, "Normative constitutional complaint in Ukraine as a national legal remedy" (Report, Venice Commission, 2018), accessed on 15 November 2019, https://www.venice.coe.int/webforms/documents/?pdf=CDLJU(2018)015-e.

57 Supra, note 20. 
Being urged to prefer the individual freedom to the economic security, Ukrainian lawmakers upheld both in the 1996 Constitution of Ukraine. Members of the Working Group of the Constitutional Commission, playing a key role in drafting the constitution, were committed to the ideal of personal autonomy in the social state. The first head of the Constitutional Court and chairman of the group Leonid Yuzkov in 1992 co-authored with a member of the group Yevheniia Tykhonova article saying in the civilized state human is the center of social life, based on liberty, natural rights, honor, and dignity; such state integrates people within its territory in civil society, that is an association of free and equal autonomous persons..$^{8}$ Member of the group Volodymyr Kopieichykov in the 1991 book "Democracy and Personality" wrote:

"A person isn't a passive product of social interactions but a living and active agent characterized by autonomy in the own development and by internal structure differing from the social. Freedom is inherent to individual independent in self-formation, activity, and development."59

In 2004 decision the Court interpreted constitutional principle of the rule of law as the supremacy of law in a society demanding that the State should embody this principle into law-making and law-enforcement activities, in particular, into the statute laws, which essentially should be permeated above all by the ideas of social justice, freedom, and equality. ${ }^{60}$

According to the 2012 decision of the Court, Ukraine as a social state recognizes the human being as the highest social value and distributes the public wealth according to the principles of social justice. It is mindful of the consolidation of public consent in society. The main objective of the social state is the creation of conditions for implementation of social, cultural and economic human rights, the facilitation of independence and responsibility of every person for his or her actions and the provision of social assistance for those citizens who cannot provide a sufficient standard of living for themselves and their families due to circumstances beyond their control. ${ }^{6}$

\footnotetext{
$5^{8}$ Leonid Yuzkov and Yevheniia Tykhonova, "Konstytutsiia yurydychna i faktychna [Juridical and factual constitution]," Law of Ukraine 1 (1992): 9.

59 Volodymyr Kopieichykov, "Narodovlastie i lichnost [Democracy and Personality]" (Kyiv: Ukraina, 1991).

6o No 15-rp/2004 of 2 November 2004 (Decision of the Constitutional Court of Ukraine, 2004).

${ }_{61}$ No 3-rp/2012 of 25 January 2012 (Decision of the Constitutional Court of Ukraine, 2012).
} 
Another 2012 decision of the Court emphasized that right to personal autonomy is necessary for full development of human in democratic society because of natural voluntarily and dynamism of human behavior, independency of individual from the state, local self-government, and other juridical and physical persons, especially in the spheres of private and family life where individual is free to define his or her behaviour and the extent to which others can become familiar with it, as stated in the Constitution and Civil Code of Ukraine. ${ }^{62}$

The Court recognized not only the personal autonomy, but further autonomy of groups and organizations aimed to realize social and cultural rights, namely autonomy of religious groups in assembling without permission of local authorities ${ }^{63}$ and autonomy of workers to create trade unions without overcomplicated bureaucratic procedure, ${ }^{64}$ declaring unconstitutional restrictive legislation rooted in the Soviet past. In 2001 decision the Court ruled that Ukraine as a social state must support organizations of civic society, but defended the autonomy of NGOs declaring unconstitutional provisions of the legislation requiring youth and children organizations should be members of one particular nationwide coalition to apply for public funding. ${ }^{65}$ Interestingly, in 2004 decision on unconstitutionality of compulsory age limit of 65 years imposed by the law on candidates to academic positions the Court literally upheld the autonomy and self-governance of higher education institutions ${ }^{66}$ - the principle proclaimed in the initial draft Constitution of 1992 but removed during political squabbles next years. Indeed, the principle of autonomy was comprehensively developed by the Court.

Principle of equality in socio-economic rights was applied by Constitutional Court of Ukraine, for example, in 1999 opinion declared unconstitutional draft law amending the Constitution of Ukraine by the entitlement to a guaranteed old-age pension from the age of 55 years for women and 60 years for men on the ground that citizens' right to social protection is guaranteed to all citizens

\footnotetext{
62 No 2-rp/2012 of 20 January 2012 (Decision of the Constitutional Court of Ukraine, 2012).

63 No 6-rp/2016 of 8 September 2016 (Decision of the Constitutional Court of Ukraine, 2016).

64 No 11 -rp/2000 of 18 October 2000 (Decision of the Constitutional Court of Ukraine, 2000).

65 No 18-rp/2001 of 13 December 2001 (Decision of the Constitutional Court of Ukraine, 2001).

66 No 14 -rp/2004 of 7 July 2004 (Decision of the Constitutional Court of Ukraine, 2004).
} 
and does not depend on the age they reach, ${ }^{67}$ and in 2002 decision declared unconstitutional immunity of the deputies of local councils against dismissal from their main job in other organizations without preliminary consent of local council on the ground that labor rights of all citizens should be protected equally by the courts. ${ }^{68}$

These examples of legal reasoning of the Constitutional Court of Ukraine represent its doctrine of social justice, based on the values of the rule of law, liberal democracy, social state, personal (group, organizational) autonomy, and equality in economic, social, and cultural rights guaranteed by the Constitution of Ukraine.

\subsection{Constitutional Justice in Times of Economic and Political Turbulence}

The life expectancy of average national constitution was estimated as 19 years. ${ }^{69}$ Constitution of Ukraine survived 23 years, for now, and the Constitutional Court of Ukraine contributed a lot to make it happen. Particularly remarkable is its tendency to protect economic, social, and cultural rights avoiding extremities of squander and shortages.

For example, according to the data of the World Bank, ${ }^{70}$ in 1998 , inflation in Ukraine was $10.6 \%$ which was twice higher than overall global inflation $5.3 \%$. 23 July 1998 Verkhovna Rada adopted the Law on the temporary prohibition of raising the prices and tariffs for housing, municipal services, and public transport provided to citizens of Ukraine; the law prescribed to freeze mentioned prices and tariffs at the level of 1 July 1998. The President of Ukraine has challenged the law in the Constitutional Court of Ukraine. 2 March 1999, the Court decided the law is unconstitutional and void because the parliament interfered with the powers of government to implement price policies contrary to the constitutional principle of the separation of powers. ${ }^{71} 16$ March 1999 Verkhovna Rada adopted

\footnotetext{
${ }_{67}$ No 2-v/1999 of 2 June 1999 (Opinion of the Constitutional Court of Ukraine, 1999).

68 No 6-rp/2002 of 26 March 2002 (Decision of the Constitutional Court of Ukraine, 2002).

69 Zachary Elkins et al., The Endurance of National Constitutions (Cambridge University Press, 2009).

70 "Inflation, consumer prices (annual \%) - Ukraine, World (1997-2001)," The World Bank Data, accessed on 15 November 2019, https://data.worldbank.org/indicator/FP.CPI.TOTL.ZG?end=2001\&locations=UA-1W\&start=1997.

${ }^{71}$ No 2-rp/99 of 2 March 1999 (Decision of the Constitutional Court of Ukraine, 1999).
} 
proclamation accusing the Court and the President in violation of socioeconomic rights, emphasizing that wage arrears are exceed 10 million hryvnas (near $8 \%$ of GDP) and workers are deprived of means for living.72 The same day the government and the National Bank of Ukraine informed International Monetary Fund (IMF) about the progress in liberalization of prices as part of economic reforms supported by IMF; according to the memorandum of economic policies, delays in obtaining a ruling by the Constitutional Court prevented the increase in tariffs for communal services in 1998, but, following the decision of the Constitutional Court, tariffs for gas and electricity (services regulated by the central government) planned to be increased by $25 \%$ and $20 \%$ respectively. ${ }^{73} 17$ March 1999 the parliament amended the Law on prices and pricing, freezing prices in case of arrears of wages or social benefits and obliging the government to coordinate with the parliament any changes in prices and tariffs; that amendment 10 February 2000 the Court avoided as non-constitutional. ${ }^{74}$ After the attempts of parliament to freeze the prices, inflation was reached $22.7 \%$ in 1999 and $28.2 \%$ in 2000; after the Court cancelled these price regulations, in 2001, inflation was dropped to $12 \%$. Hypothetically, in case of inability of the Court to strike down populist legislation Ukraine was doomed to hyperinflation as it happened in Zimbabwe, where stubborn attempts to freeze prices forcedly reduced almost to nothing value of national currency and fastened social degradation, caused tendencies like food shortages in agrarian economy. ${ }^{75}$

Further case law of the Court shows a balanced approach to protection of the socio-economic rights in the circumstances of the financial difficulties of the state. In 2007, decision it declared unconstitutional annual termination of welfare rights by the law on the state budget, ${ }^{76}$ but in 2011 the Court emphasized

\footnotetext{
72 Verkhovna Rada of Ukraine, "Proclamation of the Verkhovna Rada of Ukraine Concerning the Cancellation by the Constitutional Court of Ukraine of the Law of Ukraine on the Temporary Prohibition of Rising the Prices and Tariffs for Housing, Municipal Services, and Public Transport Provided to Citizens of Ukraine" (16 March 1999).

73 International Monetary Fund, "Ukraine Letter of Intent and Memorandum of Economic Policies," 16 March 1999, https://www.imf.org/external/np/loi/1999/031799.htm.

74 No 2-rp/2000 of 10 February 2000 (Decision of the Constitutional Court of Ukraine, 2000).

75 Michael Winesjuly, "Zimbabwe Price Controls Cause Chaos," New York Times, 3 July 2007, https://www.nytimes. com/2007/07/03/world/africa/o3cnd-wzimbabwe.html.

76 No 6-rp/2007 of 9 July 2007 (Decision of the Constitutional Court of Ukraine, 2007).
} 
the social and economic rights envisaged in the legislation are not absolute ${ }^{77}$ and in 2012 decision the Court interpreted the principle of social state as protection of needs in social security within the limits of the financial capacity of the state obliged to keep the budget balanced distributing public wealth in fair and non-discriminatory way..$^{7}$ In 2018 , deciding the limitation of child benefits is constitutional79 the Court made reference to 2007 statement of the Committee on Economic, Social and Cultural Rights, saying: where the available resources are demonstrably inadequate, the obligation remains for a State party to ensure the widest possible enjoyment of economic, social and cultural rights under the prevailing circumstances. ${ }^{80}$ Unfortunately, this obligation neglected in Ukraine at the level of public policy; it demonstrates problem of non-enforcement of judgments, most of them in social security cases, according to Committee of Ministers of the Council of Europe (CM CoE), persistent since 2004 because of insufficient compliance of authorities. ${ }^{81}$ As admitted Baulin, there are no necessary funds in the state budget to execute judgments of the ECtHR, ${ }^{{ }_{2}}$ including pilot judgment in the case of Yuriy Nikolayevich Ivanov v. Ukraine and next landmark judgment in the case of Burmych and Others v. Ukraine ordered CM CoE to deal with 12143 admissible complaints about violations of the right to a fair trial by non-enforcement of domestic judgments in Ukraine. ${ }^{83}$

In 2019, Ukrainian Helsinki Human Rights Union informed CM CoE the government allocated in the state budget only 600 million UAH (near 22 million EUR) to pay the debt before the victims of non-enforcement of judgments which is much less than needed annual payment; total estimated amount of the debt exceeds 1 billion EUR. ${ }^{84}$ It can't be said that the state is unable to pay the debt,

\footnotetext{
77 No 20-rp/2011 of 26 December 2011 (Decision of the Constitutional Court of Ukraine, 2011).

78 Supra, note 61.

79 Supra, note 2.

8o United Nations, "Economic and Social Council, An Evaluation Of The Obligation To Take Steps To The "Maximum Of Available Resources" Under An Optional Protocol To The Covenant: Statement of the Committee On Economic, Social And Cultural Rights" (E/C.12/2007/1, 21 September 2007).

${ }_{81}$ H46-35Yuriy Nikolayevich Ivanov, Zhovner group and Burmych and Others v. Ukraine: Supervision of the execution of the European Court's judgments, CM/Del/Dec(2019)1348/H46-35 (Council of Europe, Committee of Ministers, 6 June 2019).

82 Supra, note 22.

${ }_{83}$ Case of Burmych and Others v. Ukraine, dated 12 October 2017 (Judgment of the European Court of Human Rights, 2017).

84 Reply from the authorities (22/08/2019) following a communication from a NGO (25/07/2019) in the cases of
} 
since military spending in Ukraine increased almost 7 times last 5 years, to 3.8 billion EUR; only $2 \%$ of debt is planned to repay in 2020 , while military budget increased by 560 million EUR, the sum sufficient to pay a half of debt instead. Despite President Volodymyr Zelensky was recently elected after his campaigning to stop the war, he personally and proudly announced an increase in the war budget with no mention that such expenses will be taken at the cost of socioeconomic stagnation and further decline of the rule of law.

By 2004 memorandum Ukraine took obligation before IMF to strengthen the rule of law, implementing a comprehensive reform of the judicial system;;5 in 2010, Ukraine also promised to IMF further reforms on the issue of judicial enforcement due to resolve the problem of non-payment of loans. ${ }^{86}$ Consequently, the law adopted in 2011 prescribed raise of court fees 4 times in civil cases and 8 times in administrative cases. In the interests of social development, civil associations were exempted from a court fee for taking legal action to protect the rights of their members. To ensure the exemption will not be abused, on the request of nonprofit economic association aimed in collective management of copyright the Constitutional Court of Ukraine officially interpreted this exemption as non-applicable to organisations of collective management of property rights because these organizations are not civil associations; ${ }^{87}$ the Court's interpretation contained profiteering from enforcement of extortive copyright regimes, according to Shaheed, harmful to personal autonomy in scope of creative, artistic and academic freedom, opportunities to participate in cultural life and enjoy the benefits of scientific progress as guaranteed by the article 15 of ICESCR. ${ }^{88}$

In 2015 Ukraine promised IMF a selective increase of court fees, aiming to double court fee revenues, as well as establishment of private enforcement

Burmych and Others, Ivanov and Zhovner group v. Ukraine, Applications No. 46852/13, 40450/04, 56848/00 (Council of Europe, Committee of Ministers, 23 August 2019).

${ }_{5}$ International Monetary Fund, "Ukraine - Letter of Intent, Memorandum of Economic and Financial Policies and Technical Memorandum of Understanding," 11 March 2004, https://www.imf.org/external/np/loi/2004/ukr/01/ index.htm.

86 International Monetary Fund, "Ukraine: Letter of Intent, and Technical Memorandum of Understanding," 10 December 2010, https://www.imf.org/external/np/loi/2010/ukr/121010.pdf.

87 No 12-rp/2013 of 28 November 2013 (Decision of the Constitutional Court of Ukraine, 2013).

88 United Nations, Human Rights Council, "Report of the Special Rapporteur in the field of cultural rights, Farida Shaheed: Copyright policy and the right to science and culture" (A/HRC/28/57, 24 December 2014). 
profession with consequent changes in fees for enforcement of judgments. ${ }^{89} \mathrm{New}$ economic barriers in access to justice were noted in 2017 during universal periodic review of Ukraine. ${ }^{90}$ Reacting to challenge, in 2019, Constitutional Court of Ukraine issued decision in Khlipalska case upon individual constitutional complaint of woman denied in compulsory enforcement of a judgment ordered the state tax office to answer her public information request because she was unable to make advance payment required by the law in the sum of two minimum wages; she argued it is prohibitive amount of advance payment depriving unwealthy people the possibility to pursue enforcement of court decisions in their favor. The Court declared unconstitutional the provisions of Article 26.2 of the Law of Ukraine "On Enforcement Proceedings" about mandatory payment in advance by the person in whose favor the court decision was adopted, as a necessary condition to begin the enforcement of such decision by the state executive service, by the reason that said financial burden is incompatible with a constitutional principle of binding force of judgments. ${ }^{11}$

The Court's protection of human rights was especially significant in politically sensitive cases, such as the case of constitutionality of the power of the Ministry of Finance of Ukraine to access personal data which the ministry used to suspend payment of pensions to internally displaced persons (IDPs) alleging $30-40 \%$ of $1.7 \mathrm{mln}$ registered IDPs are fraudsters because they still live in the areas controlled by separatists after supposed displacement. ${ }^{22}$ According to report of the Council of Europe Project "Strengthening the Human Rights Protection of Internally Displaced Persons in Ukraine", hundreds of thousands of IDPs have not been displaced by the armed conflict in the Eastern Ukraine itself, but as a result of having to cross to government-controlled areas (GCAs) and register as IDPs, as national legislation currently conditions payment of

\footnotetext{
89 "Ukraine: Letter of Intent, Memorandum of Economic and Financial Policies, and Technical Memorandum of Understanding," International Monetary Fund, 27 February 2015, https://www.imf.org/external/np/loi/2015/ ukr/022715.pdf.

90 United Nations, Human Rights Council, "Summary of Stakeholders' submissions on Ukraine: Report of the Office of the United Nations High Commissioner for Human Rights" (A/HRC/WG.6/28/UKR/3, 31 August 2017).

91 No 2-r(II)/2019 of 15 May 2019 (Decision of the Constitutional Court of Ukraine, 2019).

92 BBC Ukraine, "Minfin shukatyme shakhraiv sered tykh, komu platiat dopomohu [Ministry of Finances seeks for fraudsters among recipients of social benefits]," 1 March 2016, https://www.bbc.com/ukrainian/ business/2016/03/160301_verification_social_benefits_az.
} 
pensions to persons from GCAs on IDP registration; the report urged Ukraine to protect privacy of IDPs and repeal all legislation demanding civilians from the conflict areas must register as IDPs to get their pensions. ${ }^{93}$ Constitutional Court of Ukraine declared unconstitutional provision of the Budget Code of Ukraine allowed the Ministry of Finance to access personal data of IDPs. ${ }^{94}$ Despite the government constantly tries to suspend pensions to as many as possible IDPs, number of registered IDPs was decreased to $1.4 \mathrm{mln},{ }^{95}$ not to $1-1.2 \mathrm{mln}$ as was intended after the unconstitutional monitoring of personal data, which shows that the Court's decision protected access to pensions for approximately 200 to 400 thousands of civilians whose right to social security was infringed both by the conflict in the Eastern Ukraine and anti-social policies.

Upholding the rule of law and human rights, the Constitutional Court of Ukraine managed to preserve values of social justice in the times of armed conflict, indebtedness, and austerity. It was achieved without direct economic analysis of law, which may be useful to apply in the future to check whether particular economic policies are socially responsible, and to calculate proper sum of damages caused by violations of human rights for further repayment by the order of the court.

\subsection{Case Law and Impact of Decisions of the Constitutional Court of Ukraine Protecting Economic, Social, and Cultural Rights}

As I mentioned before, guarantees of economic, social and cultural rights in the Constitution of Ukraine was critically received by the European experts immediately after the adoption of the basic law. Especially, Venice Commission in 1997 opinion expressed skepticism about justiciability of the rights to housing, to health protection, and to a sufficient standard of living. The case law of Constitutional Court of Ukraine shows the rights are justiciable, at least in conservative interpretation (aimed to protect vulnerable groups).

93 Council of Europe, Enhancing the National Legal Framework in Ukraine for Protecting the Human Rights of Internally Displaced Persons (Kyiv, 2016).

94 No 7-r/2018 of 11 October 2018 (Decision of the Constitutional Court of Ukraine, 2018).

95 Ministry of Social Policy of Ukraine, "Vnutrishnio peremishcheni osoby [Internally displaced persons]," accessed 15 November 2019, https://www.msp.gov.ua/timeline/Vnutrishno-peremishcheni-osobi.html. 
The Court ensured fairness during privatization of the state-owned housing in the decision recognized right to privatize free of charge more than one apartment in total size within the limits of sanitary norm, which envisages 21 square meters of total floor space per tenant and every member of his or her family and an additional 10 square meters per family. ${ }^{96}$ In other decision, the Court ruled that military personnel don't require registration of place of residence to obtain housing. ${ }^{97}$ Also, the Court recognized that protection from eviction of retired workers from service quarters includes those who retired early, ${ }^{98}$ for example, due to damages to health caused by Chernobyl disaster. In 2018 the Court proclaimed unconstitutional legislative amendments restricting the social benefits available to persons affected by the catastrophe;99 after the decision, budgetary funding of the benefits was increased by $12 \%$ to protect fully their right to a sufficient standard of living. ${ }^{100}$

In 1998, Constitutional Court of Ukraine decided to declare unconstitutional the decree of government in part concerning the list of paid medical services in public health care system on the ground that the constitutional right to health protection, medical care and medical insurance (Article 49 of the Constitution) guarantees that medical care must be provided free of charge in state and municipal medical facilities. ${ }^{101}$ Also, in 2002, the Court decided the Article 49 means that the state-owned and communal health protection institutions shall provide medical care to every citizen irrespective of its scope and without prior, immediate or subsequent payment for such care, but the scope of the medical care, system of public and private medical insurance, as well as the procedures for granting medical services beyond the basic free-of-charge medical care on a paid basis in state and public health institutions, and the list of such services, must be laid down by the law. ${ }^{102}$ These decisions of the Court became cornerstones of the legal regulation of the national system of the protection of health in

\footnotetext{
96 No 15-rp/2010 of 10 June 2010 (Decision of the Constitutional Court of Ukraine, 2010).

97 No 11-rp/2002 of 13 June 2002 (Decision of the Constitutional Court of Ukraine, 2002).

$9^{8}$ No 6-rp/2014 of 11 June 2014 (Decision of the Constitutional Court of Ukraine, 2014).

99 No 6-r/2018 of 17 June 2018 (Decision of the Constitutional Court of Ukraine, 2018).

100 Law of Ukraine on Amendments to the Law of Ukraine about the State Budget of 2018.

101 No 15-rp/1998 of 25 November 1998 (Decision of the Constitutional Court of Ukraine, 1998).

${ }_{102}$ No 10-rp/2002 of 29 May 2002 (Decision of the Constitutional Court of Ukraine, 2002).
} 
Ukraine, which is funded at the level 3.4 bln EUR in 2019, or approximately 9\% of total budgetary spending. ${ }^{103}$

Similar decision the Court made upholding the constitutional right to free primary education in 2002. It declared unconstitutional provisions of the decree of the Cabinet of Ministers of Ukraine making payable use of textbooks in public elementary schools which must be free of charge according to the Constitution of Ukraine. ${ }^{104}$

The Court also protected dignity and personal autonomy of individuals restricted in their legal capacity for mental illness. 2018 decision declared unconstitutional provision of the Law on Citizens' Appeals restricting the ability of such persons to petition the authorities, for example, asking for necessary measures to improve their welfare; the Court ruled incapacitated individuals must be allowed to submit petitions in person, not only through a guardian, under Article 40 of the Constitution giving everyone the right to file individual or collective written petitions which must be considered and answered by the authorities. ${ }^{105}$ It shows the Court cares about the justiciability of socio-economic rights both as the collective rights and the individual rights, helping every person in need to be heard by the state.

\section{CONCLUSION}

Ukraine ratified the International Covenant on Economic, Social, and Cultural Rights in 1973 as a formally sovereign republic in the Soviet Union. These rights were embedded in the constitutional law and guaranteed by wellfinanced policies of the state. Access to the exercise of these rights was regulated on the base of loyalty to a communist regime, which severely restricted civil and political rights, preventing the judiciary from interference, in particular, allowing no independent constitutional review. After the collapse of a socialist economy, dissolution of the USSR, and proclamation of independence of Ukraine

\footnotetext{
${ }_{103}$ Law of Ukraine on the State Budget of 2019.

104 No 18-rp/2002 of 21 November 2002 (Decision of the Constitutional Court of Ukraine, 2002).

105 No 8-r/2018 of 11 October 2018 (Decision of the Constitutional Court of Ukraine, 2018).
} 
in 1991, socio-economic rights were severely limited to ensure the economic and political transition from socialism to democracy, especially, free-market reforms, democratic nation-building, as well as protection of the civil and political rights oppressed in the past. All the time, international observers noted grave violations of human rights in the country.

The Constitution of Ukraine adopted in 1996 enshrined high standards of human rights and established the Constitutional Court of Ukraine that ensured fairness of further transition, upholding economic, social, and cultural rights in times of crises and conflicts. Independent constitutional review by the judiciary in post-communist Ukraine helped the nation to make progress in compliance with international human rights law, which was also noted by international experts and represents valuable experience for other nations in transition. Human rights enshrined by ICESCR are universally recognized in the contemporary world, as points out Strydom, ${ }^{106}$ so, every civilized nation should protect it, in particular via legal adjudication.

Retired Judge Hultai in 2018 and other experts of Venice Commission in 1996-1997 spoke critically about the justiciability of socio-economic rights in principle. However, our research shows the Constitutional Court of Ukraine is capable to deliver necessary judgments that are enforced by the state, restoring social justice for hundreds of thousands of people. Moreover, contrary to the criticism of conservative measures like striking down a law and individualized rights enforcement, such measures, seen as insufficient by some comparative scholars, in practice became adequate to nudge legal and political system towards social justice.

After more than two decades of functioning, the Court developed impressive doctrine and case law to protect economic, social and cultural rights enshrined in the Constitution of Ukraine and international human rights treaties. These include the rights to free development of personality, to work, freely chosen and fairly paid, in healthy labor conditions; as well as rights to rest and leisure; to

${ }_{106}$ Hennie Strydom, "The Protection of Economic, Social and Cultural Rights in International Law," Constitutional Review 5, no. 2 (2019): 222-247. 
create trade unions, to strike, and other labor rights; rights to social security, to a sufficient standard of living, including adequate nutrition and clothing; rights to housing, to health protection, to education, to the freedom of literary, artistic, scientific and technical creative activities, to protection of intellectual property, to protection of family, childhood, motherhood and fatherhood; and so on.

In the official interpretation and application of relevant constitutional provisions, the Court is dedicated to the principles of the rule of law, equality, and social justice. Furthermore, the Court implemented in its legal reasoning the ideas of personal autonomy, close to liberal democratic views expressed in academic publications of the framers of the Constitution in first years after the proclamation of independence of Ukraine. In several decisions, the Court protected the privacy of individuals, as well as the autonomy of NGOs, trade unions, and religious groups from restrictive regulations and unjustified intrusions.

Despite enormous pressure, the Court found a pragmatic balance between the values of individual freedom and economic security, helping Ukraine to avoid extremities of squander and shortages in contingent times of economic and political crisis. For example, the Court canceled laws on price regulations, in such way emancipated businesses and reduced inflation, but also ruled that primary medical services and use of textbooks in public elementary schools must be free of charge to guarantee constitutional rights to education and health care.

The case of quashed price regulations also proves the hypothesis of Christian Courtis mentioned in the introduction to this article, that constitutional review helps to protect socio-economic rights at least by safeguarding the separation of powers. Defending the constitutional powers of the executive branch from illconceived, ideologically driven directive of panicking legislators, the Constitutional Court of Ukraine not only preserved the integrity of the legal and political system but secured market economy and welfare of the people depending on it.

Initial restraints in institutional autonomy of the Court, permanent pressure on judges and their reluctance to invoke economic analysis of law are marks of the imperfectness of the Court. On the other hand, empowered in 2016 with the authority to consider individual constitutional complaints, the Constitutional 
Court of Ukraine evolves for better being the cornerstone of liberal democracy, rule of law, social justice, political and economic stability, as well as sustainable development of Ukraine.

Four ways to improve constitutional review in Ukraine related to matters of social justice can be proposed: further reforms strengthening autonomy of judiciary; application of economic analysis of law to measure and compensate injustices; prioritization of the cases when immediate adjudication is needed; and deeper cooperation with civil society and expert community through human rights reporting, academic conferences and amicus curiae briefs.

\section{Appendix:}

Selected Jurisprudence of the Constitutional Court of Ukraine in Social Justice Cases

\begin{tabular}{|c|c|c|c|c|c|}
\hline $\begin{array}{l}\text { Date of } \\
\text { Decision }\end{array}$ & $\begin{array}{l}\text { Case } \\
\text { Number }\end{array}$ & $\begin{array}{l}\text { Rights at Stake } \\
\text { (Resume) }\end{array}$ & Applicant & Court's Assessment & $\begin{array}{c}\text { Dissenting } \\
\text { Opinions }\end{array}$ \\
\hline 25.11 .1998 & 15-rp/1998 & $\begin{array}{l}\text { Access to health care } \\
\text { (free-of-charge services } \\
\text { at public hospitals) }\end{array}$ & 66 MPs & $\begin{array}{l}\text { Governmental decree } \\
\text { declared partly } \\
\text { unconstitutional }\end{array}$ & o \\
\hline 2.03.1999 & 2-rp/99 & $\begin{array}{l}\text { Adequate standard of } \\
\text { living, executive powers } \\
\text { (price regulation) }\end{array}$ & $\begin{array}{l}\text { President of } \\
\text { Ukraine }\end{array}$ & $\begin{array}{l}\text { A law declared } \\
\text { unconstitutional }\end{array}$ & o \\
\hline 2.06.1999 & 2-v/1999 & $\begin{array}{l}\text { Social security (pension } \\
\text { age) }\end{array}$ & $\begin{array}{l}\text { Verkhovna } \\
\text { Rada of } \\
\text { Ukraine }\end{array}$ & $\begin{array}{l}\text { Draft law declared } \\
\text { unconstitutional }\end{array}$ & 1 \\
\hline 10.02 .2000 & $2-\mathrm{rp} / 2000$ & $\begin{array}{l}\text { Adequate standard of } \\
\text { living, executive powers } \\
\text { (price regulation) }\end{array}$ & $\begin{array}{l}\text { President of } \\
\text { Ukraine }\end{array}$ & $\begin{array}{l}\text { A law declared partly } \\
\text { unconstitutional }\end{array}$ & 2 \\
\hline 18.10 .2000 & 11-rp/2000 & $\begin{array}{l}\text { Trade unions (freedom } \\
\text { of establishment) }\end{array}$ & $\begin{array}{l}186 \text { MPs, } \\
\text { Ombudsman }\end{array}$ & $\begin{array}{l}\text { A law declared partly } \\
\text { unconstitutional }\end{array}$ & o \\
\hline 13.12 .2001 & $18-\mathrm{rp} / 2001$ & $\begin{array}{l}\text { Autonomy of youth } \\
\text { NGOs (access to } \\
\text { funding) }\end{array}$ & $51 \mathrm{MPs}$ & $\begin{array}{l}\text { A law declared partly } \\
\text { unconstitutional }\end{array}$ & o \\
\hline 26.03 .2002 & 6-rp/2002 & $\begin{array}{c}\text { Right to work (privileges } \\
\text { of deputies of local } \\
\text { councils) }\end{array}$ & $\begin{array}{l}\text { Ministry } \\
\text { of Internal } \\
\text { Affairs of } \\
\text { Ukraine }\end{array}$ & $\begin{array}{l}\text { A law declared partly } \\
\text { unconstitutional }\end{array}$ & o \\
\hline 29.05 .2002 & $\begin{array}{c}10- \\
\mathrm{rp} / 2002\end{array}$ & $\begin{array}{l}\text { Access to health care } \\
\text { (free-of-charge services } \\
\text { at public hospitals) }\end{array}$ & 53 MPs & $\begin{array}{c}\text { Constitution of } \\
\text { Ukraine interpreted } \\
\text { in favor of MPs, not } \\
\text { the executive }\end{array}$ & o \\
\hline
\end{tabular}




\begin{tabular}{|c|c|c|c|c|c|}
\hline $\begin{array}{l}\text { Date of } \\
\text { Decision }\end{array}$ & $\begin{array}{l}\text { Case } \\
\text { Number }\end{array}$ & $\begin{array}{l}\text { Rights at Stake } \\
\text { (Resume) }\end{array}$ & Applicant & Court's Assessment & $\begin{array}{c}\text { Dissenting } \\
\text { Opinions }\end{array}$ \\
\hline 13.06.2002 & $11-r p / 2002$ & $\begin{array}{l}\text { Right to housing (for } \\
\text { military servicemen; } \\
\text { financing of } \\
\text { construction) }\end{array}$ & $\begin{array}{l}\text { Ministry of } \\
\text { Defence of } \\
\text { Ukraine }\end{array}$ & $\begin{array}{l}\text { A law interpreted in } \\
\text { favor of the applicant }\end{array}$ & o \\
\hline 21.11 .2002 & $\begin{array}{c}18- \\
\mathrm{rp} / 2002\end{array}$ & $\begin{array}{l}\text { Right to education } \\
\text { (free-of-charge use of } \\
\text { textbooks) }\end{array}$ & 47 MPs & $\begin{array}{l}\text { Governmental } \\
\text { decrees are partly } \\
\text { unconstitutional }\end{array}$ & o \\
\hline 7.07 .2004 & $\begin{array}{c}14^{-} \\
\mathrm{rp} / 2004\end{array}$ & $\begin{array}{l}\text { Right to work (higher } \\
\text { education institution } \\
\text { head's maximum age) }\end{array}$ & 56 MPs & $\begin{array}{l}\text { A law declared partly } \\
\text { unconstitutional }\end{array}$ & 1 \\
\hline 2.11 .2004 & $\begin{array}{c}15^{-} \\
\mathrm{rp} / 2004\end{array}$ & $\begin{array}{l}\text { Human dignity, judicial } \\
\text { power (mitigation of } \\
\text { punishment for crime) }\end{array}$ & $\begin{array}{l}\text { Supreme } \\
\text { Court of } \\
\text { Ukraine }\end{array}$ & $\begin{array}{l}\text { A law declared partly } \\
\text { unconstitutional }\end{array}$ & 2 \\
\hline 9.07 .2007 & 6-rp/2007 & $\begin{array}{c}\text { Social security } \\
\text { (sufficient financing) }\end{array}$ & $46 \mathrm{MPs}$ & $\begin{array}{l}\text { Budget law is partly } \\
\text { unconstitutional }\end{array}$ & o \\
\hline 10.06.2010 & $15-\mathrm{rp} / 2010$ & $\begin{array}{l}\text { Right to housing } \\
\text { (privatization of } \\
\text { apartment) }\end{array}$ & Individual & $\begin{array}{l}\text { A law interpreted in } \\
\text { favor of the applicant }\end{array}$ & o \\
\hline 26.12 .2011 & 20-rp/2011 & $\begin{array}{l}\text { Social security } \\
\text { (sufficient financing) }\end{array}$ & $\begin{array}{l}49 \text { MPs; } \\
53 \text { MPs; } 56 \\
\text { MPs }\end{array}$ & $\begin{array}{l}\text { Budget law is partly } \\
\text { unconstitutional. }\end{array}$ & o \\
\hline 20.01 .2012 & $2-\mathrm{rp} / 2012$ & $\begin{array}{c}\text { Personal autonomy } \\
\text { (protection of private } \\
\text { data) }\end{array}$ & $\begin{array}{l}\text { Local } \\
\text { council }\end{array}$ & $\begin{array}{l}\text { The scope and } \\
\text { substance of } \\
\text { constitutional rights } \\
\text { were clarified }\end{array}$ & o \\
\hline 25.01 .2012 & 3-rp/2012 & $\begin{array}{c}\text { Social security, } \\
\text { executive and judicial } \\
\text { power (calculation of } \\
\text { payments) }\end{array}$ & $\begin{array}{l}\text { Pension } \\
\text { Fund of } \\
\text { Ukraine }\end{array}$ & $\begin{array}{l}\text { Constitution and laws } \\
\text { were interpreted in } \\
\text { favor of the applicant }\end{array}$ & 4 \\
\hline 28.11 .2013 & $12-\mathrm{rp} / 2013$ & $\begin{array}{l}\text { Artist rights (court fee } \\
\text { for copyright claims) }\end{array}$ & $\begin{array}{l}\text { Collecting } \\
\text { society }\end{array}$ & $\begin{array}{l}\text { Laws were interpreted } \\
\text { against the applicant }\end{array}$ & o \\
\hline 11.06 .2014 & 6-rp/2014 & $\begin{array}{l}\text { Housing (prohibition } \\
\text { of eviction of retired } \\
\text { workers from service } \\
\text { quarters) } \\
\end{array}$ & Individual & $\begin{array}{l}\text { A law interpreted in } \\
\text { favor of the applicant }\end{array}$ & o \\
\hline 8.06 .2016 & 4-rp/2016 & $\begin{array}{l}\text { Social security, } \\
\text { judicial independence } \\
\text { (limitation of judges' } \\
\text { pensions) }\end{array}$ & $\begin{array}{l}\text { Supreme } \\
\text { Court of } \\
\text { Ukraine }\end{array}$ & $\begin{array}{c}\text { Laws were } \\
\text { declared partly } \\
\text { unconstitutional }\end{array}$ & 2 \\
\hline
\end{tabular}




\begin{tabular}{|c|c|c|c|c|c|}
\hline $\begin{array}{l}\text { Date of } \\
\text { Decision }\end{array}$ & $\begin{array}{c}\text { Case } \\
\text { Number }\end{array}$ & $\begin{array}{l}\text { Rights at Stake } \\
\text { (Resume) }\end{array}$ & Applicant & Court's Assessment & $\begin{array}{l}\text { Dissenting } \\
\text { Opinions }\end{array}$ \\
\hline 8.09 .2016 & 6-rp/2016 & $\begin{array}{c}\text { Autonomy of religious } \\
\text { organizations } \\
\text { (permission for public } \\
\text { ceremonies) }\end{array}$ & Ombudsman & $\begin{array}{l}\text { A law declared partly } \\
\text { unconstitutional }\end{array}$ & 4 \\
\hline 17.06 .2018 & $6-r / 2018$ & $\begin{array}{l}\text { Social security } \\
\text { (allowances for victims } \\
\text { of Chernobyl disaster) }\end{array}$ & $50 \mathrm{MPs}$ & $\begin{array}{c}\text { Laws were } \\
\text { declared partly } \\
\text { unconstitutional }\end{array}$ & 1 \\
\hline 11.10 .2018 & $7-r / 2018$ & $\begin{array}{l}\text { Social security, privacy } \\
\text { (discrimination of IDPs) }\end{array}$ & Ombudsman & $\begin{array}{l}\text { A law declared partly } \\
\text { unconstitutional }\end{array}$ & 3 \\
\hline 11.10 .2018 & $8-r / 2018$ & $\begin{array}{l}\text { Personal autonomy of } \\
\text { mental patients (direct } \\
\text { access to justice) }\end{array}$ & Ombudsman & $\begin{array}{l}\text { A law declared partly } \\
\text { unconstitutional }\end{array}$ & o \\
\hline 7.11 .2018 & $9-r / 2018$ & $\begin{array}{l}\text { Child benefits } \\
\text { (limitation during the } \\
\text { economic crisis) }\end{array}$ & $50 \mathrm{MPs}$ & $\begin{array}{l}\text { A law declared } \\
\text { constitutional }\end{array}$ & 3 \\
\hline $15.05 \cdot 2019$ & $2-\mathrm{r}(\mathrm{II}) / 2019$ & $\begin{array}{c}\text { Enforcement of } \\
\text { judgments (economic } \\
\text { barriers) }\end{array}$ & Individual & $\begin{array}{l}\text { A law declared partly } \\
\text { unconstitutional }\end{array}$ & o \\
\hline
\end{tabular}

\section{BIBLIOGRAPHY}

Bantekas, Ilias, and Cephas Lumina, eds. Sovereign Debt and Human Rights. Oxford University Press, 2019.

Baulin, Yurii. "The Jurisprudence of the Constitutional Court of Ukraine on the Protection of Human Rights Recognized by the Ukrainian Legislation and Acts of International Law." In Global Constitutionalism and Multi-layered Protection of Human Rights - Exploring the Possibility of Establishing a Regional Human Rights Mechanism in Asia, 133-67. Seoul: Constitutional Court of Korea, 2016.

BBC Ukraine. "Minfin shukatyme shakhraiv sered tykh, komu platiat dopomohu, [Ministry of Finances seeks for fraudsters among recipients of social benefits]." 1 March 2016. https://www.bbc.com/ukrainian/business/2016/03/160301_ 
verification_social_benefits_az

Bohoslavsky, Juan Pablo, and Jernej Letnar Cernic, eds. Making Sovereign Financing and Human Rights Work. Oxford: Hart Publishing, 2016.

Budz, Iryna. "What Prevents Ukrainian Judiciary From Becoming Truly Effective And Independent?" VoxUkraine, last modified on 24 July 2019. https:// voxukraine.org/en/what-prevents-ukrainian-judiciary-from-becoming-trulyeffective-and-independent/.

Bulkat, Liudmyla. "Pytannia sotsialnoho zakhystu v aktakh Konstytutsiinoho Sudu Ukrainy [The issue of social protection in the acts of the Constitutional Court of Ukraine.]" University Scientific Notes 58 (2016): 23-34.

Chinkin, Christine. "The Protection of Economic, Social and Cultural Rights PostConflict." Paper series commissioned by the Office of the High Commissioner for Human Rights (2009). http://www2.ohchr.org/english/issues/women/ docs/Paper_Protection_ESCR.pdf.

Chubar, Liudmyla. "Problemy realizatsii sotsialnykh prav na suchasnomu etapi ta yikh zakhyst u konstytutsiinomu sudochynstvi [Contemporary problems of realization of social rights and its defense in constitutional justice.]" The Herald of the Constitutional Court of Ukraine 6 (2003):111-4.

Coalition for Personal Autonomy. "Ukraine: problems with implementation of the International Covenant on Economic, Social and Cultural Rights." Pravdoshukach, 31 August 2018. https://truth.in.ua/en/public/358/.

Conclusion of 26 October 1990 in the case No 11(2-1) concerning legislation on propiska of citizens, Committee of Constitutional Supervision of the USSR. Constitution (The Basic Law) of the Ukrainian Soviet Socialist Republic of 1937. Constitution (The Basic Law) of the Ukrainian Soviet Socialist Republic of 1978. Constitution of Ukraine, adopted 28 June 1996.

Constitutional Court of Ukraine. "Konstytutsiina yustytsiia ta rynkova ekonomika: suchasni ta perspektyvni naukovo-praktychni realii [Constitutional Justice 
and Market Economy: Contemporary Scientific and Practical Trends and Prospects]." Accessed on 15 November 2019. http://www.ccu.gov.ua/novyna/ konstytuciyna-yustyciya-ta-rynkova-ekonomika-suchasni-ta-perspektyvninaukovo-praktychni.

Constitutional Court of Ukraine. "The Acts of CCU.” Accessed on 15 November 2019. http://ccu.gov.ua/en/storinka/acts-ccu.

Council of Europe. Enhancing the National Legal Framework in Ukraine for Protecting the Human Rights of Internally Displaced Persons. Kyiv: 2016.

Council of Europe, Venice Commission. "Meeting on the draft Constitution of Ukraine: Secretariat memorandum, CDL(1993)o42-e." 25 June 1993.

Council of Europe, Venice Commission. "Opinion on the Constitution of Ukraine, CDL-INF(1997)oo2-e." 11 March 1997.

Council of Europe, Venice Commission. "Opinion on the draft Constitution of Ukraine, CDL-INF(1996)oo6-e." 21 May 1996.

Council of Europe, Venice Commission. "Opinion on the present constitutional situation in Ukraine following the adoption of the Constitutional Agreement between the Supreme Rada of Ukraine and the president of Ukraine, CDL(1995)o40-e." 11 September 1995.

Council of Europe, Venice Commission. "The CODICES database." Accessed on 15 November 2019. http://www.codices.coe.int.

Courtis, Christian. Courts and the Legal Enforcement of Economic, Social and Cultural Rights: Comparative Experiences of Justiciability. Geneva: International Commission of Jurists, 2008.

Decision in case No 15-rp/1998 of 25 November 1998, Constitutional Court of Ukraine (Ukraine).

Decision in case No 2-rp/99 of 2 March 1999, Constitutional Court of Ukraine (Ukraine).

Decision in case No 2-rp/200o of 10 February 2000, Constitutional Court of Ukraine (Ukraine). 
Decision in case No 11-rp/200o of 18 October 2000, Constitutional Court of Ukraine (Ukraine).

Decision in case No 18-rp/2001 of 13 December 2001, Constitutional Court of Ukraine (Ukraine).

Decision in case No 6-rp/2002 of 26 March 2002, Constitutional Court of Ukraine (Ukraine).

Decision in case No 10-rp/2002 of 29 May 2002, Constitutional Court of Ukraine (Ukraine).

Decision in case No 11-rp/2002 of 13 June 2002, Constitutional Court of Ukraine (Ukraine).

Decision in case No 18-rp/2002 of 21 November 2002, Constitutional Court of Ukraine (Ukraine).

Decision in case No 14-rp/2004 of 7 July 2004, Constitutional Court of Ukraine (Ukraine).

Decision in case No 15-rp/2004 of 2 November 2004, Constitutional Court of Ukraine (Ukraine).

Decision in case No 6-rp/2007 of 9 July 2007, Constitutional Court of Ukraine (Ukraine).

Decision in case No 15-rp/2010 of 10 June 2010, Constitutional Court of Ukraine (Ukraine).

Decision in case No 20-rp/2011 of 26 December 2011, Constitutional Court of Ukraine (Ukraine).

Decision in case No 2-rp/2012 of 20 January 2012, Constitutional Court of Ukraine (Ukraine).

Decision in case No 3-rp/2012 of 25 January 2012, Constitutional Court of Ukraine (Ukraine).

Decision in case No 12-rp/2013 of 28 November 2013, Constitutional Court of Ukraine (Ukraine). 
Decision in case No 6-rp/2014 of 11 June 2014, Constitutional Court of Ukraine (Ukraine).

Decision in case No 4-rp/2016 of 8 June 2016, Constitutional Court of Ukraine (Ukraine).

Decision in case No 6-rp/2016 of 8 September 2016, Constitutional Court of Ukraine (Ukraine).

Decision in case No 6-r/2018 of 17 June 2018, Constitutional Court of Ukraine (Ukraine).

Decision in case No 7-r/2018 of 11 October 2018, Constitutional Court of Ukraine (Ukraine).

Decision in case No 8-r/2018 of 11 October 2018, Constitutional Court of Ukraine (Ukraine).

Decision in case No 9-r/2018 of 7 November 2018, Constitutional Court of Ukraine (Ukraine).

Decision in case No 2-r(II)/2019 of 15 May 2019, Constitutional Court of Ukraine (Ukraine).

Elkins, Zachary, et al. The Endurance of National Constitutions. Cambridge University Press, 2009.

Faiz, Pan Mohamad. "A Prospect and Challenges for Adopting Constitutional Complaint and Constitutional Question in the Indonesian Constitutional Court." Constitutional Review 2, no. 1 (2016): 103-28. http://dx.doi.org/10.31078/ consrev215.

Gregory, Paul R., and Irwin L. Collier Jr. "Unemployment in the Soviet Union: Evidence from the Soviet Interview Project." The American Economic Review 78, no. 4 (1988): 613-32.

H46-35 Yuriy Nikolayevich Ivanov, Zhovner group and Burmych and Others v. Ukraine: Supervision of the execution of the European Court's judgments, CM/Del/Dec(2019)1348/H46-35 (Council of Europe, Committee of Ministers, 6 June 2019). 
Hausmaninger, Herbert. "The Committee of Constitutional Supervision of the USSR." Cornell International Law Journal 23, no. 2 (1990): 287-322.

Holovaty, Serhiy. "Concept of the Rule of Law - Difficulties of its perception in the post-Soviet legal culture (Ukraine's experience)." Report, Venice Commission, 2016. Accessed on 15 November 2019, https://www.venice.coe. int/webforms/documents/?pdf=CDL-JU(2016)o15-e.

Holovin, Anatolii. "15 Years of Constitutional Justice in Ukraine: Accomplishments, Challenges, Prospects." In The Protection of Human Rights by Bodies Of Constitutional Justice: Possibilities And Problems of Individual Access. Materials of International Conference, 411-24. Kyiv: Logos, 2011.

Hultai, Mykhailo. "Normative constitutional complaint in Ukraine as a national legal remedy." Report, Venice Commission, 2018, accessed on 15 November 2019, https://www.venice.coe.int/webforms/documents/?pdf=CDL-JU(2018)o15-e.

Iarskaia-Smirnova, Elena, and Karen Lyons. "Social Work in Former Soviet Union Countries: Mapping the Progress of 'The Professional Project." European Journal of Social Work 21, no. 1 (2018): 114-27. https://doi.org/10.1080/13691 457.2016.1255926.

Inshyn, Mykola, Yurii Miroshnychenko, and Yurii Paida. "Protection Of Constitutional Cultural Rights and Freedoms of Citizens by The Constitutional Court of Ukraine." Baltic Journal of Economic Studies 4, no. 4 (2018): 134-9. https://doi.org/10.30525/2256-0742/2018-4-4-134-139.

International Commission of Jurists. "Ukraine: dismissal and criminal prosecution of judges undermine independence of the judiciary." Last modified on 20 March 2014, https://www.icj.org/ukraine-dismissal-and-criminal-prosecutionof-judges-undermine-independence-of-the-judiciary/.

International Monetary Fund. "Ukraine - Letter of Intent, Memorandum of Economic and Financial Policies and Technical Memorandum of Understanding." 11 March 2004, https://www.imf.org/external/np/loi/2004/ ukr/o1/index.htm. 
International Monetary Fund. "Ukraine Letter of Intent and Memorandum of Economic Policies." 16 March 1999, https://www.imf.org/external/np/ loi/1999/031799.htm.

International Monetary Fund. "Ukraine: Letter of Intent, and Technical Memorandum of Understanding." 10 December 2010, https://www.imf.org/ external/np/loi/2010/ukr/121010.pdf.

International Monetary Fund. "Ukraine: Letter of Intent, Memorandum of Economic and Financial Policies, and Technical Memorandum of Understanding." 27 February 2015, https://www.imf.org/external/np/loi/2015/ ukr/o22715.pdf.

Judgment of 12 October 2017 in the case of Burmych and Others v. Ukraine, European Court of Human Rights.

Kopieichykov, Volodymyr. Narodovlastie i lichnost' [Democracy and Personality]. Kyiv: Ukraina, 1991.

Landau, David. “The Reality of Social Rights Enforcement." Harvard International Law Journal 53, no. 1 (Winter 2012): 189-247.

Law of Ukraine on Amendments to the Law of Ukraine about the State Budget of 2018 year.

Law of Ukraine on the State Budget of 2019.

LB.ua. "Yanukovych charged with constitutional coup. Ex-Justice Minister Lavrynovych is another suspect in the case." last modified on 6 September 2017, https://en.lb.ua/news/2017/og/o6/4436_yanukovych_charged.html.

Michalowski, Sabine. "Sovereign Debt and Social Rights - Legal Reflections on a Difficult Relationship." Human Rights Law Review 8, no. 1 (2008): 35-68. https://doi.org/10.1093/hrlr/ngmo42.

Ministry of Social Policy of Ukraine. "Vnutrishnio peremishcheni osoby [Internally displaced persons]." Accessed 15 November 2019, https://www.msp.gov.ua/ timeline/Vnutrishno-peremishcheni-osobi.html. 
Odling-Smee, John, et al. Ukraine: IMF Economic Reviews. Washington: International Monetary Fund, 1995.

Opinion in case No 2-v/1999 of 2 June 1999, Constitutional Court of Ukraine (Ukraine).

Popova, Maria. “Ukraine's Politicized Courts." In Beyond the Euromaidan: Comparative Perspectives on Advancing Reform in Ukraine, edited by Henry E. Hale and Robert W. Orttung, 143-61. Stanford University Press, 2016.

Reply from the authorities (22/08/2019) following a communication from a NGO (25/07/2019) in the cases of Burmych and Others, Ivanov and Zhovner group v. Ukraine, Applications No. 46852/13, 40450/o4, 56848/oo (Council of Europe, Committee of Ministers, 23 August 2019).

Ricón, José Luis. “The Soviet Union: Achieving full employment.” Nintil, accessed on 15 November 2019, https://nintil.com/the-soviet-union-achieving-fullemployment/.

Roosevelt, Eleanor. "Human Rights." In Peace on Earth, 65-71. New York: Hermitage House, 1949.

Sheliazhenko, Yurii. "Autonomous Processual Model of Law." Philosophy of Law and General Theory of Law 1 (2019): 91-111. https://doi.org/10.21564/22277153.2019.1.186739.

Ssenyonjo, Manisuli. Economic, Social and Cultural Rights in International Law. Oxford: Hart Publishing, 2009.

Strydom, Hennie. "The Protection of Economic, Social and Cultural Rights in International Law." Constitutional Review 5, no. 2 (2019): 222-247. https:// doi.org/10.31078/consrev522.

Swaminathan, Rajesh. "Regulating Development: Structural Adjustment and the Case for National Enforcement of Economic and Social Rights." Columbia Journal of Transnational Law 37, no. 1 (1998):161.

Trochev, Alexei. "Fragmentation? Defection? Legitimacy? Explaining Judicial Roles in Post-Communist Colored Revolutions." In Consequential Courts: 
Judicial Roles in Global Perspective, edited by Diana Kapiszewski, Gordon Silverstein, and Robert A. Kagan, 67-92. Cambridge University Press, 2013.

Tymchenko, Ivan. "Mechanism of Constitutional Jurisdiction in Defence of Rights and Freedoms of Man and Citizen." In The Legal System of Ukraine: Past, Present, and Future. Volume II. Constitutional Foundations of the Legal System of Ukraine and Problems of Improvement, edited by Yurii Bytiak et al., 121-47. Kharkiv: Pravo, 2013.

UN Office of the High Commissioner for Human Rights. Economic, Social and Cultural Rights: Handbook for National Human Rights Institutions. New York and Geneva: United Nations, 2005.

UN Office of the High Commissioner for Human Rights. Transitional Justice and Economic, Social and Cultural Rights. Geneva: United Nations, 2014.

United Nations, Economic and Social Council. "An Evaluation of the Obligation to Take Steps to the Maximum of Available Resources Under an Optional Protocol to the Covenant: Statement of the Committee On Economic, Social And Cultural Rights." E/C.12/2007/1, 21 September 2007.

United Nations, Economic and Social Council. "Committee on Economic, Social and Cultural Rights Twenty-sixth (extraordinary) session: summary record of the 41st meeting." E/C.12/2001/SR.41 (28 August 2001).

United Nations, Economic and Social Council. "Implementation of the International Covenant on Economic, Social and Cultural Rights. Second periodic reports submitted by States parties to the Covenant concerning rights covered by articles 6 to 9 in accordance with the first stage of the programme established by the Economic and Social Council in its resolution 1988 (LX): Ukranian Soviet Socialist Republic." E/1984/7/Add.9, 13 March 1984.

United Nations, Economic and Social Council. "Reports submitted in accordance with Council resolution 1988 (LX) by states parties to the International Covenant on Economic, Social and Cultural Rights covered by articles 6 to 9: Ukranian Soviet Socialist Republic." E/1978/8/Add.22, 26 September 1978. 
United Nations, Economic and Social Council. "Sessional working group on the implementation of the International Covenant on Economic, Social and Cultural rights: summary record of the 18th meeting." E/1980/WG.1/SR.18, 28 April 1980.

United Nations, Economic and Social Council. "Sessional working group of governmental experts on the implementation of the International Covenant on Economic, Social and Cultural rights: summary record of the 15th meeting." E/1984/WG.1/SR.15, 30 April 1984.

United Nations, Economic and Social Council. "Ukraine: Implementation of the International Covenant on Economic, Social and Cultural Rights. Third periodic reports submitted by States parties under articles 16 and 17 of the Covenant." E/1994/104/Add.4, 17 October 1994.

United Nations, Human Rights Council. "Report of the Special Rapporteur in the field of cultural rights, Farida Shaheed: Copyright policy and the right to science and culture." A/HRC/28/57, 24 December 2014.

United Nations, Human Rights Council. "Summary of Stakeholders' submissions on Ukraine: Report of the Office of the United Nations High Commissioner for Human Rights." A/HRC/WG.6/28/UKR/3, 31 August 2017.

United Nations. "Vienna Declaration and Programme of Action." World Conference on Human Rights, A/CONF.157/23, 12 July 1993.

Verkhovna Rada of Ukraine. "Proclamation of the Verkhovna Rada of Ukraine Concerning the Cancellation by the Constitutional Court of Ukraine of the Law of Ukraine on the Temporary Prohibition of Rising the Prices and Tariffs for Housing, Municipal Services, and Public Transport Provided to Citizens of Ukraine." 16 March 1999.

Verkhovna Rada of Ukraine. "Legislation of Ukraine." accessed on 15 November 2019, https://zakon.rada.gov.ua/laws?lang=en.

Verlanov, Serhii. Ekonomichni i sotsialni prava liudyny: yevropeiski standarty ta yikh vprovadzhennia $v$ yurydychnu praktyku Ukrainy (zahalnoteoretychne 
doslidzhennia) [Economic and social rights of human: European standards and their implementation in judicial practice in Ukraine (broad theoretical research)]. Lviv: Krai, 2009.

Winesjuly, Michael. "Zimbabwe Price Controls Cause Chaos." New York Times, 3 July 2007, https://www.nytimes.com/2007/07/o3/world/africa/o3cndwzimbabwe.html.

Wolczuk, Kataryna. The Moulding of Ukraine: The Constitutional Politics of State Formation. Budapest: Central European University Press, 2001.

World Bank Data. "Inflation, consumer prices (annual \%) - Ukraine, World (1997-2001)."Accessed on 15 November 2019. https://data.worldbank.org/ indicator/FP.CPI.TOTL.ZG?end=2001\&locations $=U A-1$ W\&start $=1997$.

Yuzkov, Leonid, and Yevheniia Tykhonova. "Konstytutsiia yurydychna i faktychna [Juridical and factual constitution]." Law of Ukraine 1 (1992): 9.

Yuzkov, Leonid. Constitution of Soviet Ukraine. Kyiv: Politvidav Ukraini Publishers, 1984. 